\title{
Mix Design of Self Compacting Concrete Using Fly Ash and Microsilica
}

\author{
Ashok P. Kalbande ${ }^{1}$, Shriya A. Kalbande ${ }^{2}$ \\ ${ }^{1}$ Assistant Professor, HOD Civil Engineering Department, GWCET, Nagpur \\ ${ }^{2}$ Assistant Professor, Real Institute Of Management, Nagpur
}

\begin{abstract}
Self compacting concrete is firstly developed in Japan in 1980; Self compacting concrete is a fluid mixture suitable for placing in structures with congested reinforcement without vibration. Self compacting concrete development must ensure a good balance between deformability and stability also, compatibility is affected by the characteristics of materials and the mix proportions, self compacting concrete is a concrete that exhibits high deformability while maintaining resistance to segregation. Self compacting concrete construction and placing becomes faster and easier it eliminates the need for vibration and reducing the noise pollution; which consumes both time and labor.
\end{abstract}

Keywords: SSC, vibration, mix proportion, compacting, pollution

\section{Introduction}

Microsilica is a very fine pozzolanic material, as a byproduc $\mathrm{t}$ of the production of elemental silicon or ferro silicon.

Microsilica is an admixture used to enhance the properties of concrete. It is specifically used to produce self compacting concrete with high strength, more workability and other beneficial properties. Self-compacting concrete (SCC) is a flowing concrete mixture. The highly fluid nature of SCC makes it suitable for placing in difficult condition \& in selections with congested reinforcement. Use of SCC can help in hearing related damages on the worksite that are induced by vibration of concrete, another advantages of SCC is that the time required to place large section in consider ability reduced. It is recently used at Mumbai for Bandra-Warli Sea Link Bridge.

\section{Mix Design (For M20)}

1) Concrete Specification

Strength: Characteristic Compressive Strength $($ Fck $)=$ $20 \mathrm{~N} / \mathrm{mm}^{2}$

Workability: $=$ Medium

Workability (IS: 456 2000)

\begin{tabular}{|c|c|c|}
\hline Placing Conditions & $\begin{array}{l}\text { Degree of } \\
\text { Workability }\end{array}$ & $\begin{array}{l}\text { Slump } \\
(\mathrm{mm})\end{array}$ \\
\hline (1) & (2) & (3) \\
\hline $\begin{array}{l}\text { Blinding concrete; } \\
\text { Shallow sections; }\end{array}$ & Very low & See 7.1.1 \\
\hline Pavements using pavers & & \\
\hline $\begin{array}{l}\text { Mass concrete; } \\
\text { Lightly reinforced } \\
\text { sections in slabs, } \\
\text { heams, walls, columns; } \\
\text { Floors; } \\
\text { Hand placed pavements: } \\
\text { Canal lining; } \\
\text { Strip footings }\end{array}$ & Low & $25-75$ \\
\hline $\begin{array}{l}\text { Heavily reinforced } \\
\text { sections in slats, } \\
\text { beams, walls, columns; }\end{array}$ & Medium & $\begin{array}{r}50-100 \\
75-100\end{array}$ \\
\hline $\begin{array}{l}\text { Slipform work; } \\
\text { Pumped concrete }\end{array}$ & & \\
\hline $\begin{array}{l}\text { Trench fill: } \\
\text { In-situ piling }\end{array}$ & High & $100-150$ \\
\hline Tremie concrete & Very high & See 7.1 .2 \\
\hline
\end{tabular}

Volume 6 Issue 12, December 2017 www.jisr.net 


\section{International Journal of Science and Research (IJSR) \\ ISSN (Online): 2319-7064}

Index Copernicus Value (2016): 79.57 | Impact Factor (2015): 6.391

Table: Environmental Exposure Condition (IS: 456 2000)

\begin{tabular}{|c|c|c|}
\hline $\begin{array}{l}\text { Si No. } \\
\text { (1) }\end{array}$ & $\begin{array}{l}\text { Enviroament } \\
\text { (2) }\end{array}$ & $\begin{array}{l}\text { Exposure Conditions } \\
\text { (3) }\end{array}$ \\
\hline i) & Mild & $\begin{array}{l}\text { Concrete surfaces protected against } \\
\text { weather or aggressive conditions, except } \\
\text { those situated in coastal area. }\end{array}$ \\
\hline \multirow[t]{5}{*}{ ii) } & Moderate & $\begin{array}{l}\text { Concrete surfaces sheltered from severe } \\
\text { rain or froezing whilst wet }\end{array}$ \\
\hline & & Concrete exposed to condensation and rain \\
\hline & & Concrete continuously under water \\
\hline & & $\begin{array}{l}\text { Concrete in contact or bwried under non- } \\
\text { aggressive soil/ground water }\end{array}$ \\
\hline & & $\begin{array}{l}\text { Concrete surfaces sheitered from } \\
\text { saturated salt air in coastal area }\end{array}$ \\
\hline \multirow[t]{3}{*}{ ii) } & Severe & $\begin{array}{l}\text { Concrete surfaces exposed to severe } \\
\text { rain, alternate wetting and drying or } \\
\text { occasional freezing whilst wet or severe } \\
\text { condensation. }\end{array}$ \\
\hline & & Concrete completely immersed in sea water \\
\hline & & Concrete exposed to coastal environment \\
\hline \multirow[t]{2}{*}{ iv) } & Very severe & $\begin{array}{l}\text { Concrete surfaces exposed to sea water } \\
\text { spray, corrosive fumes or severe freezing } \\
\text { conditions whilst wet }\end{array}$ \\
\hline & & $\begin{array}{l}\text { Concrete in contact with or buried } \\
\text { under ageressive sub-soil/ground water }\end{array}$ \\
\hline \multirow[t]{2}{*}{ v) } & Extreme & Surface of memben in tidal zone \\
\hline & & $\begin{array}{l}\text { Members in direct contact with liquid/ } \\
\text { solid agressive chemicals }\end{array}$ \\
\hline
\end{tabular}

\section{Materials Properties}

a) Fine Aggregates

Zone $\quad=$ Zone 1
Table: Grading limit for fine aggregate (IS: 383-1970)

\begin{tabular}{|c|c|c|c|c|c|}
\hline IS Sieve & $\begin{array}{c}\text { Equivalent } \\
\text { BS Sieve }\end{array}$ & Zone-1 & Zone-2 & Zone-3 & Zone-4 \\
\hline 10-mm & $3 / 8-$ in & 100 & 100 & 100 & 100 \\
\hline $\mathbf{4 . 7 5 - m m}$ & $3 / 16-$-in & $90-100$ & $90-100$ & $90-100$ & $95-100$ \\
\hline $\mathbf{2 . 3 6}-\mathbf{m m}$ & No. 7 & $60-95$ & $75-100$ & $85-100$ & $95-100$ \\
\hline $\mathbf{1 , 1 8}-\mathbf{m m}$ & No. 14 & $30-70$ & $55-90$ & $75-100$ & $90-100$ \\
\hline $\mathbf{6 0 0 -}$ micron & N0. 25 & $15-34$ & $35-59$ & $60-79$ & $80-100$ \\
\hline 300-micron & No, 52 & $5-20$ & $8-30$ & $12-40$ & $15-50$ \\
\hline 150-micron & No. 100 & $0-10$ & $0-10$ & $0-10$ & $0-15$ \\
\hline
\end{tabular}

Specific Gravity $\quad=2.2$

Dry Loose Bulk Density (DLBD) $=1.39 \mathrm{Kg} / \mathrm{lit}$

b) Coarse Aggregates

Specific Gravity $\quad=2.58$

Dry Loose Bulk Density $(\mathrm{DLBD})=1.45 \mathrm{Kg} / \mathrm{lit}$

Maximum Aggregate Size $\quad=30 \mathrm{~mm}$

c) Cement

Type of Cement $(\mathrm{Fm}) \quad=$ OPC 53 Grade

Standard Deviation $(\mathrm{s}) \quad=20.7 \mathrm{Kg} / \mathrm{cm} 3$

Characteristic Strength of cement $(\mathrm{Fc})=49.58 \mathrm{~N} / \mathrm{mm} 2$

$(\mathrm{Fc}=\mathrm{Fm}-1.65 \mathrm{~s})$

Cement Grade = Grade " $\mathrm{D}$ "

28 - Day Strength of Cement tested according to (IS : 40311968)

\begin{tabular}{|cccc|}
\hline 28 & - Day Strength of Cement tested according to IS : $4031-1968$ \\
A & $31.9-36.8 \mathrm{~N} / \mathrm{mm}^{2}$ & E & $51.5-56.4 \mathrm{~N} / \mathrm{mm}^{2}$ \\
B & $36.8-41.7 \mathrm{~N} / \mathrm{mm}^{2}$ & F & $56.4-61.3 \mathrm{~N} / \mathrm{mm}^{2}$ \\
C & $41.7-46.6 \mathrm{~N} / \mathrm{mm}^{2}$ & G$^{*}$ & $61.3-66.2 \mathrm{~N} / \mathrm{mm}^{2}$ \\
D & $46.6-51.5 \mathrm{~N} / \mathrm{mm}^{2}$ & & \\
\hline
\end{tabular}

Maximum W/C ratio $=0.55$

Table Maximum water-cement ratio (IS:456 2000)

Table 5 Minimum Cement Content, Maximum Water-Cement Ratio and Minimum Grade of Concrete for Different Exposures with Normal Weight Aggregates of 20 mm Nominal Maximum Size

(Clauses 6.1.2, 8.2.4.1 and 9.1.2)

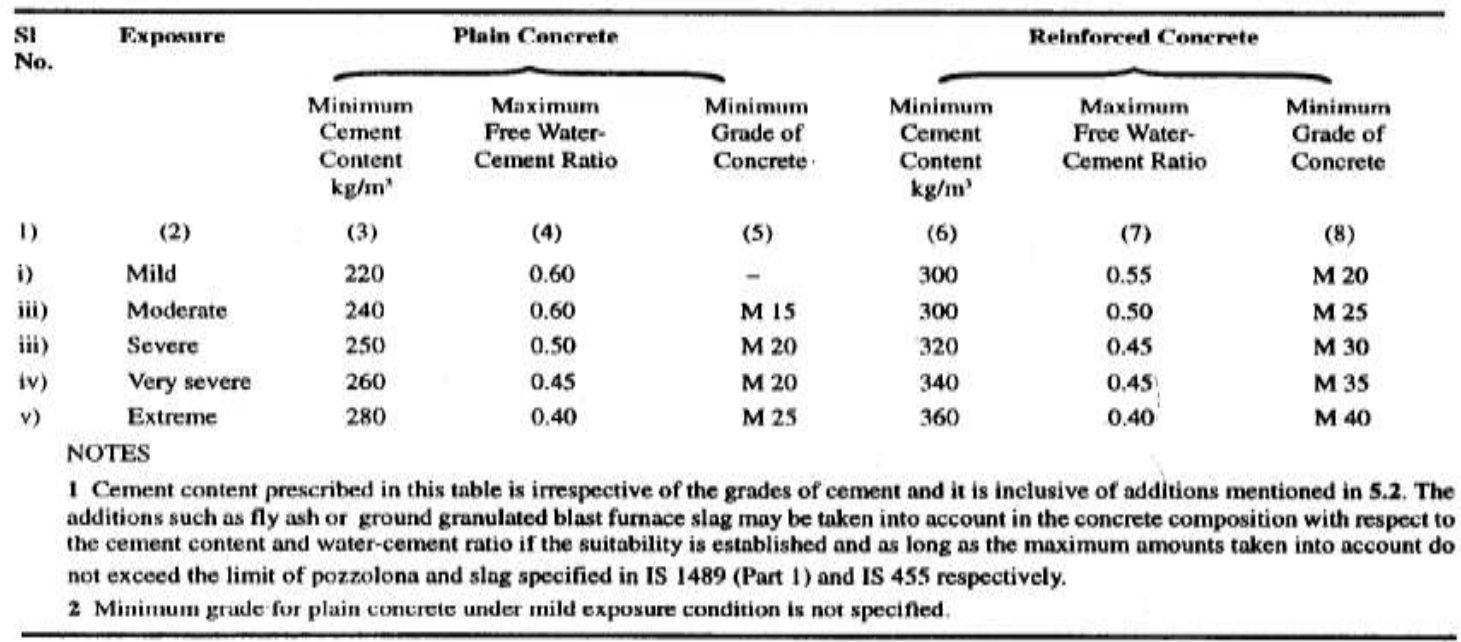

Volume 6 Issue 12, December 2017 www.ijsr.net 
1) Minimum Cement Content $=285 \mathrm{Kg} / \mathrm{m}^{3}$

2) Slump - in $\mathrm{mm} \quad=75 \mathrm{~mm}$.

3) Slump - Degree in workability $=$ Medium

4) Target Strength

Standard Deviation's

Value of ' $\mathrm{t}$ '

$=5 \mathrm{~N} / \mathrm{mm}^{2}$

$=1.65$

Table: Assumed Standard Deviation (IS: 456 2000)

Table 8 Assumed Standard Deviation

(Clause 9.2.4.2 and Table II)

\begin{tabular}{|c|c|}
\hline $\begin{array}{l}\text { Grade of } \\
\text { Concrete }\end{array}$ & $\begin{array}{l}\text { Assumed Standard } \\
\text { Deviation } \\
\mathrm{N} / \mathrm{mm}^{2}\end{array}$ \\
\hline 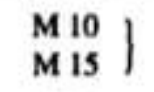 & 3.5 \\
\hline $\begin{array}{l}\mathrm{M} 20 \\
\mathrm{M} 25\end{array} \mid$ & 4.0 \\
\hline $\begin{array}{l}\text { M } 30 \\
\text { M } 35 \\
M \quad 40 \\
M \quad 45 \\
M \quad 50\end{array} \mid$ & 5.0 \\
\hline
\end{tabular}

NOTE-The above values correspond to the site control having proper storage of cement; weigh batching of all materials; controlled addition of water, reguiar checking of all matorials, aggregate gradings and moisture content; and periodical checking of workability and strength. Where there is deviation from the above the values given in the above table shall be increased by $1 \mathrm{~N} / \mathrm{mm}^{2}$.

Table: Value of " $t$ " (IS: 10262-1982)

\begin{tabular}{|l|l|}
\hline Acceptance proportion of low result & "t" \\
\hline 1 in 5 & 0,84 \\
\hline 1 in 10 & 1.28 \\
\hline 1 in 15 & 1.50 \\
\hline 1 in 20 & 1,65 \\
\hline 1 in 40 & 1,96 \\
\hline 1 in 100 & 2.33 \\
\hline
\end{tabular}

Target Mean Strength Fm $=28.25 \mathrm{~N} / \mathrm{mm}^{2}$

$(\mathrm{Fm}=\mathrm{Fck}+\mathrm{t}$ x s

Relation between free water/cement ratio and concrete strength at 28 days for different Cement curves (IS: 10262-1982)

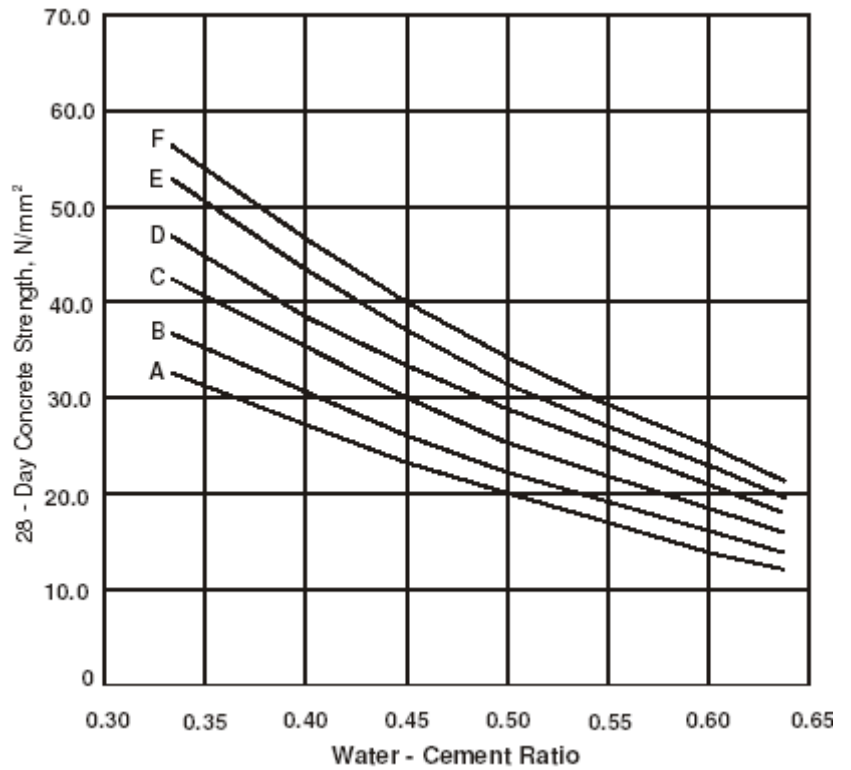

8. Water - Cement ratio [W/C] $($ from Graph) $=0.48$

9. Final W/C

$=0.48$

$\begin{array}{lcll}C & \text { FA } & \text { CA } & \text { Water } \\ 1 & 2.23 & 2.5 & 0.48\end{array}$

Mix Proportion

Table: mix proportion for 1 cubic meter of concrete.

\begin{tabular}{|c|c|c|c|c|c|c|c|}
\hline Mixture & $\begin{array}{c}\text { Cement } \\
\left(\mathrm{Kg} / \mathrm{m}^{3}\right)\end{array}$ & $\begin{array}{c}\mathrm{SF} \\
\left(\mathrm{Kg} / \mathrm{m}^{3}\right)\end{array}$ & $\begin{array}{c}\mathrm{FA} \\
\left(\mathrm{Kg} / \mathrm{m}^{3}\right)\end{array}$ & $\begin{array}{c}\text { Sand } \\
\left(\mathrm{Kg} / \mathrm{m}^{3}\right)\end{array}$ & $\begin{array}{c}\mathrm{CA} \\
\left(\mathrm{Kg} / \mathrm{m}^{3}\right)\end{array}$ & Water & $\begin{array}{c}\mathrm{SP} \\
\left(\mathrm{Kg} / \mathrm{m}^{3}\right)\end{array}$ \\
\hline CC & 404 & & & 907 & 1010 & 194 & \\
\hline CC-1 & 364 & 40 & & 907 & 1010 & 214 & \\
\hline SCC-A & 282 & 40 & 80 & 907 & 1010 & 214 & 9.67 \\
\hline SCC-B & 243 & 40 & 121 & 907 & 1010 & 214 & 9.67 \\
\hline SCC-C & 202 & 40 & 162 & 907 & 1010 & 214 & 9.67 \\
\hline
\end{tabular}

Where,

$\mathrm{CC}=$ Conventional Concrete

SCC-1 $=$ Self Compacting Concrete with $10 \%$ Microsilica.

SCC-A = Self Compacting Concrete wite 10\% Microsilica, $20 \%$ Fly Ash, \& 2.4\% Superplasticizer.

SCC-B $=$ Self Compacting Concrete wite 10\% Microsilica,

$30 \%$ Fly Ash, \& 2.4\% Superplasticizer

SCC-C $=$ Self Compacting Concrete wite 10\% Microsilica,
40\% Fly Ash, \& 2.4\% Superplasticizer

$\mathrm{SF}=$ Silica Fume or Microsilica.

$\mathrm{FA}=$ Fly Ash.

$\mathrm{CA}=$ Coarse Aggregate.

$\mathrm{SP}=$ Superplasticizer.

Volume 6 Issue 12, December 2017 www.ijsr.net

Licensed Under Creative Commons Attribution CC BY 


\section{Conclusion}

On the basis of experimentation work carried out, the following conclusions are drawn:

1) As per the observed workability and high flow ability of SCC, it can be used in highly congested reinforcement structure as compare to conventional concrete.

2) $10 \%$ replacement of microsilica for cement makes a good strength of concrete..

3) Compressive strength of conventional concrete is obtained nearly equal to the compressive strength of Self Compacting Concrete using 10\% Microsilica, 30\% fly ash and $2.4 \%$ super plasticizer.

4) On a basis of total cost, including the labors charges, formwork and making good finished surfaces, SCC can be more advantageous.

5) Fly ash is very cheap, it can be used successfully in place of cement, it gives good results at very low content.

6) At this water/cement ratio, the Slump flow test, V-funnel test, L-Box test, U-Box test result were found to be satisfactory.

\section{References}

[1] Friede Bernd - "Microsilica Charecterization Of An Unique Additive", Sao Paulo, Brazil. October 15 - 18, 2006.

[2] Md Safiuddin, S. N. Raman and M.F.M. Zain - "Effect of Different Curing Methods of the Properties of Microsilica Concrete", Australian Journal of Basic andApplied Sciences, 1(2): 87-95, 2007.

[3] Paramita Mondal, Surendra P. Shah, Laurence D. Marks, and Juan J. Gaitero - "Comparative Study of the Effects of Microsilica and Nanosilica in Concrete", Transportation Research Board of the National Academies, Washington, 2010, pp.6-9.

[4] Nausha Asrar, Anees U. Malik, Shahreer Ahmed and Fadi S. Mujahed - "CORROSION STUDIES ON MICROSILICA ADDED CEMENT IN MARINE ENVIRONMENT", Construction \& Building Materials. Vol. 13, pp. 213-219 (1999).

[5] Hoang Minh , Nguyen Tuan - "INFLUENCE OF MICROSILICA TO STEEL BAR PROTECTION ABILITY OF CONCRETE", The 3rd ACF International Conference- ACF/VCA 2008.

[6] David R. Lee - "Characterisation and the diagenetic transformation of nonand micro-crystalline silica minerals", Department of Earth and Ocean Sciences, University of Liverpool, 4 Brownlow Street, Liverpool L69 3GP, UK (2005).

[7] Abul Kalam Azad, Husain Jubran Al-Gahtani, and Shamsad Ahmad -"Chloride penetration into silica fume Concrete subject to Different Exposures".

[8] Md. Safiuddin, S.N. Raman and M.F.M. Zain "Effect of Different Curing Methods on the Properties of Microsilica Concrete".

[9] M. S. Shetti -"Textbook of Concrete Technology", S. Chand Publication.

Volume 6 Issue 12, December 2017 www.jijsr.net 